\title{
Lama Penyediaan Hijauan Pakan pada Pemeliharaan Sapi Potong di Kecamatan Loa Kulu Kabupaten Kutai Kartanegara
}

\author{
Taufan Purwokusumaning Daru1, Roosena Yusuf', Vera Rahmayanti² \\ ${ }^{1}$ Program Studi Peternakan Jurusan Peternakan Fakultas Pertanian Universitas \\ Mulawarman, Email : taufan.pd@gmail.com \\ 2Program Studi Penyuluhan Peternakan, Jurusan Peternakan Fakultas Pertanian \\ Universitas Mulawarman
}

\begin{abstract}
The aim of the research was to find out the distance of farmers in obtaining forage for beef cattle and the duration of the provision of forage for beef cattle. The research was conducted by using survey method through observational approach with interview techniques directly to farmers with the questionnaire. The location specified in the purposive sampling with criteria of intensive farming system. The data analyzed by quantitative descriptive and multiple regression. The results showed that the distance of farmers to provide fodder ranged between $113 \mathrm{~m}$ up to $1000 \mathrm{~m}$ at Sumber Sari Village, Loa Kulu district, Kutai Kartanegara regency. The feed supply duration time spent by farmers ranged between 1,167 seconds (19 minutes 27 seconds) up to 2,270 seconds (37 minutes 50 seconds). The feeding time for one cattle ranged from 28 seconds up to 126 minutes (2 minutes 6 seconds). The factor that affect feed supply duration time was long mileage. The factors that affect time of feeding were methods of feeding and feeding frequency. Keywords: beef cattle, distance, feeding, forage, time
\end{abstract}

\section{ABSTRAK}

Tujuan penelitian adalah untuk mengetahui jarak yang ditempuh oleh petani dalam memperoleh hijauan pakan dan mengetahui waktu yang diperlukan dalam pemberian hijauan pakan. Penelitian menggunakan metode survei melalui pendekatan observasi dengan teknik wawancara langsung kepada peternak sapi potong dengan kuesioner. Lokasi penelitian ditentukan secara purpossive sampling dengan kriteria sistem pemeliharaan intensif. Metode analisis data menggunakan analisis deskriptif kuantitatif dan analisis regresi berganda. Hasil penelitian menunjukkan bahwa jarak yang ditempuh oleh peternak di Desa Sumber Sari Kecamatan Loa Kulu Kabupaten Kutai Kartanegara dalam menyediakan hijauan pakan untuk satu ekor sapi berkisar antara $113 \mathrm{~m}$ sampai dengan $1.000 \mathrm{~m}$. Lama penyediaan pakan untuk satu ekor sapi berkisar antara 1.167 detik (19 menit 27 detik) sampai dengan 2.270 detik (37 menit 50 detik). Lama pemberian pakan yang berkisar antara 28 detik sampai dengan 126 detik (2 menit 6 detik). Faktor yang mempengaruhi lama penyediaan pakan adalah jarak tempuh. Faktor-faktor yang mempengaruhi lama pemberian pakan adalah cara pemberian pakan dan frekuensi pemberian pakan.

Kata kunci: jarak, hijauan pakan, jarak, pemberian pakan, sapi potong, waktu

\section{Pendahuluan}

Tatalaksana peternak dalam menyediakan pakan untuk memenuhi kebutuhan pemberian pakan ternak mengandalkan pada tatalaksana mencari, mengambil dan membawa pakan ternak sendiri setiap hari dengan jarak tempuh yang cukup jauh dari lokasi kandang dan kebiasaan peternak dalam sekali penyediaan pakan, akan dilakukan penyediaan pakan lebih untuk mempersiapkan pemberian pakan dalam satu hari yang memerlukan waktu yang cukup lama. Penerapan tatalaksana tersebut menyebabkan skala kepemilikan ternak kecil. 
Kabupaten Kutai Kartanegara memiliki luas wilayah $27.263,10 \mathrm{~km}^{2}$ dan perairan \pm $4.097 \mathrm{~km}^{2}$. Perkembangan ternak di Kabupaten Kutai Kartanegara selalu menunjukkan pergerakan yang positif. Peningkatan ternak potong yang paling menonjol pada tahun 2015 yakni ternak sapi dan kambing. Populasi ternak pada tahun 2015, ternak sapi tercatat 27.508 ekor naik meningkat $5 \%$ dari tahun sebelumnya yakni sebanyak 26.198 ekor (Badan Pusat Statistik Kabupaten Kutai Kartanegara, 2016a). Keputusan Menteri Pertanian Republik Indonesia Nomor: 43/Kpts/PD.410/1/2015 menyatakan, Kabupaten Kutai Kartanegara merupakan salah satu kawasan yang telah ditetapkan sebagai kawasan sapi potong.

Kecamatan Loa Kulu merupakan salah satu lokasi kawasan sapi potong di Kabupaten Kutai Kartanegara. Menurut Data Badan Pusat Statistik Kecamatan (2016b), ternak di Kecamatan Loa Kulu meliputi sapi potong, kerbau, kambing dan babi. Populasi paling tinggi adalah sapi potong yaitu 3.621 ekor.

Kawasan pengembangan sapi potong di Kecamatan Loa Kulu salah satunya adalah Desa Sumber Sari. Skala pemeliharaan sapi potong di Desa Sumber Sari masih kecil sehingga peternak belum sepenuhnya memperhitungkan manajemen pakan seperti memperhitungkan jarak dan waktu yang mereka gunakan untuk menyediakan pakan ternak. Waktu yang dihabiskan oleh peternak untuk memelihara ternak merupakan biaya pengeluaran tenaga kerja yang dapat memperhitungkan keuntungan dalam suatu usaha dan waktu yang paling lama digunakan dalam pemeliharaan ternak sapi adalah penyediaan pakan untuk pemberian pakan ternak.

\section{Metode Penelitian}

Penelitian dilakukan di Desa Sumber Sari Kecamatan Loa Kulu Kabupaten Kutai Kartanegara pada bulan Maret sampai dengan April 2017. Lokasi penelitian dilakukan Provinsi Kalimantan Timur. Penelitian dilakukan pada saat keadaan pertanian di lokasi penelitian sedang dalam masa olah lahan padi sawah. Responden dari penelitian sebagian besar bermata pencaharian sebagai petani. Bahan dan alat yang digunakan pada penelitian antara lain alat tulis, alat dokumentasi, alat pengukur waktu, alat pengukur jarak, timbangan dan kuesioner dengan sasaran responden atau peternak sapi potong di Desa Sumber Sari. Jumlah responden dalam penelitian ini sebanyak 28 peternak. Sampel ditentukan secara purposive sampling berdasarkan jumlah ternak dengan sistem pemeliharaan dikandang terbanyak. Penentuan jumlah sampel menggunakan rumus Slovin (Darmawan, 2013).

$$
n=\frac{N}{1+N(e)^{2}}
$$

Keterangan :

$\mathrm{n} \quad=$ Sampel 
$\mathrm{N} \quad=$ Populasi

e $\quad=$ Derajat ketelitian atau nilai kritis yang diinginkan (15\%)

Jumlah sampel berdasarkan rumus Slovin diketahui sebanyak 28 orang responden. Untuk pengambilan sampel dilakukan dengan teknik stratified random sampling dengan jumlah sampel dalam setiap stratum ditentukan secara proportional karena pada penelitian ini populasi terdiri dari kelas yaitu kelompok ternak yang memiliki jumlah anggota kelompok yang berbeda. Penentuan jumlah sampel dalam setiap kelompok ternak adalah sebagai berikut :

Sampel sub kelompok $=\frac{\text { jumlah masing-masing kelompok }}{\text { jumlah populasi }} \times$ besaran sampel

Hasil perhitungan rumus penentuan jumlah sampel secara proportional adalah pada kelompok pertama dengan anggota kelompok 62 orang peternak akan diambil sampel sebanyak 23 orang peternak sedangkan pada kelompok kedua dengan anggota kelompok sebanyak 12 orang peternak akan diambil sampel sebanyak 5 orang peternak.

Analisis data untuk mengetahui jarak tempuh dalam penyediaan pakan satu ekor ternak sapi pada usaha pemeliharaan ternak sapi potong menggunakan rumus persamaan statistik sederhana, yaitu:

$$
J_{i}=\frac{j_{i}}{t_{i}}
$$

Keterangan :

$J \quad=$ Jarak tempuh penyediaan pakan satu ekor ternak sapi potong

$j \quad=$ Jumlah jarak tempuh

$t \quad=$ Jumlah ternak

$i \quad=$ Alat transportasi meliputi;

a (jalan kaki), b (sepeda), c (sepeda motor) dan d (mobil pick up)

Analisis data untuk mengetahui lama penyediaan pakan satu ekor ternak sapi pada usaha pemeliharaan ternak sapi potong menggunakan rumus:

$$
Y_{n i}=\frac{w_{n 1 i}+w_{n 2 i}+w_{n 3 i}}{t_{i}}
$$

Keterangan :

$Y_{n}=$ Lama penyediaan pakan untuk satu ekor ternak sapi

$w_{n 1}=$ Waktu mencari pakan

$w_{n 2}=$ Waktu mengambil pakan

$w_{n 3}=$ Waktu membawa pakan

$t \quad=$ Jumlah ternak

$i \quad=$ Alat transportasi meliputi;

a (jalan kaki), b (sepeda), c (sepeda motor) dan d (mobil pick up) 
Analisis data untuk mengetahui lama pemberian pakan satu ekor ternak sapi pada usaha pemeliharaan ternak sapi potong menggunakan rumus:

$$
Y_{m o}=\frac{\sum y_{m o}}{t_{o}}
$$

Keterangan :

$$
\begin{aligned}
Y_{m} \quad= & \text { Lama pemberian pakan untuk satu ekor ternak sapi } \\
\sum y_{m}= & \text { Jumlah lama pemberian pakan } \\
t \quad= & \text { Jumlah ternak } \\
o \quad= & \text { Cara pemberian pakan meliputi; } \\
& \text { a (secara langsung) dan } \mathrm{b} \text { (perlakuan khusus) }
\end{aligned}
$$

Analisis data untuk mengetahui faktor-faktor yang mempengaruhi lama penyediaan pakan pada usaha pemeliharaan ternak sapi potong menggunakan analisis regresi linier berganda sebagai berikut:

a. Persamaan regresi linier berganda

Persamaan regresi linier berganda tiga variabel sebagai berikut (Siregar, 2014) :

$Y=a+b_{1} x_{1}+b_{2} x_{2}+b_{3} x_{3}$

Keterangan :

$\mathrm{Y}=$ Lama waktu penyediaan pakan

$a=$ konstanta

$b_{n}=$ koefisien

$x_{1}=$ Jarak tempuh

$x_{2}=$ Jumlah pakan

$x_{3}=$ Alat transportasi

\section{Hasil Dan Pembahasan}

\section{Keadaan Umum Lokasi Penelitian}

Desa Sumber Sari merupakan bagian dari wilayah Kecamatan Loa Kulu Kabupaten Kutai Kartanegara. Luas wilayah yang berpotensi sebagai lahan pertanian. Luas wilayah yang berpotensi sebagai lahan pertanian di Desa Sumber Sari disajikan pada Tabel 1.

Tabel 1. Luas wilayah Desa Sumber Sari menurut penggunaan lahan

\begin{tabular}{clc}
\hline No. & \multicolumn{1}{c}{ Luas wilayah menurut penggunaan } & Luas (ha) \\
\hline 1. & Luas tanah sawah & 436,00 \\
2. & Luas tanah kering & 497,00 \\
3. & Luas tanah basah & 10,00 \\
4. & Luas tanah perkebunan & 271,00 \\
5. & Luas fasilitas umum & 174,00 \\
6. & Luas tanah hutan & 28,00 \\
\hline Total luas & $\mathbf{1 . 4 1 6 , 0 0}$ \\
\hline
\end{tabular}

Ternak yang terdapat di Desa Sumber Sari meliputi sapi, kerbau, kambing, ayam buras, ayam broiler, itik, angsa, burung puyuh dan kelinci. Populasi ternak di Desa Sumber Sari disajikan pada Tabel 2. 
Umur responden di Desa Sumbersari diklelompokan pada rentang umur 21 - 65 tahun $(89,29 \%)$ dan rentang umur > 65 tahun $(10,71 \%)$. Suku yang terdapat di Desa Sumbersari adalah Jawa (82,14\%), Dayak (7,14\%). Kutai (7,14\%) dan Bugis (3,57\%). Ratarata pengalaman beternak responden di Desa Sumbersari berkisar dari 1 tahun sampai $>$ 50 tahun. Sebagian besar peternak memiliki pengalaman beternak $1-50$ tahun. Pendidikan terakhir sebagian besar responden tamat SD (60,71\%), tamat SLTP $(4,29 \%)$, tamat SLTA $17,86 \%$, dan tamat PT (7,14\%). Mata pencaharian penduduk di Desa Sumber Sari mayoritas adalah petani $(82,14 \%)$ dan sebagian besar dari responden bermata pencaharian sebagai petani yang memelihara ternak sapi potong, selebihnya adalah sebagai PNS dan pekerja bangunan. Jumlah kepemilikan ternak sapi pada kisaran 1 - 5 ekor (85,71\%), 6 - 10 ekor (10,71\%), dan > 10 ekor (3,57\%).

Tabel 2 Populasi ternak di Desa Sumber Sari

\begin{tabular}{|c|c|c|c|}
\hline No. & Jenis Ternak & Jumlah Pemilik (orang) & Jumlah Populasi (ekor) \\
\hline 1. & Sapi & 143 & 733 \\
\hline 2. & Kerbau & 6 & 14 \\
\hline 3. & Kambing & 233 & 745 \\
\hline 4. & Ayam buras & 1.678 & 7.718 \\
\hline 5. & Ayam pedaging & 2 & 766 \\
\hline 6. & Itik & 1.666 & 13.332 \\
\hline 7. & Angsa & 23 & 51 \\
\hline 8. & Burung puyuh & 5 & 10.655 \\
\hline 9. & Kelinci & 4 & 24 \\
\hline
\end{tabular}

\section{Jarak Tempuh Penyediaan Hijauan Pakan}

Jarak yang ditempuh oleh peternak dalam menyediakan pakan untuk satu ekor ternak sapi pada usaha pemeliharaan ternak sapi potong di Desa Sumber Sari dikelompokkan berdasarkan alat transportasi yang digunakan oleh peternak. Jarak yang tempuh oleh peternak dalam menyediakan pakan untuk satu ekor ternak sapi pada usaha pemeliharaan ternak sapi potong, disajikan pada Tabel 3.

Tabel 3 Jarak tempuh penyediaan hijauan pakan

\begin{tabular}{clc}
\hline No. & \multicolumn{1}{c}{ Alat Trasportasi } & $\begin{array}{c}\text { Jarak Tempuh } \\
(\mathrm{m})\end{array}$ \\
\hline 1. & Jalan kaki (a) & 113 \\
2. & Sepeda (b) & 225 \\
3. & Sepeda motor (c) & 211 \\
4. & Mobil Pick up (d) & 1000 \\
\hline
\end{tabular}

Peternak di Desa Sumber Sari memiliki kebiasaan dalam penyediaan pakan. Peternak menyediakan pakan saat musim kemarau dengan memanfaatkan hijauan pakan ternak yang terdapat disekitar lahan budidaya pertanian. Saat musim hujan sebagian peternak menyediakan pakan dengan memanfaatkan lahan budidaya hijauan pakan yang dimiliki. Sebagian peternak lainnya yang lahan budidaya hijauan pakan terkena banjir ataupun tidak memiliki lahan budidaya hijauan pakan, peternak menyediakan pakan 
dengan cara mencari hijauan pakan ternak dari dusun ke dusun, dari desa ke desa bahkan dari satu kecamatan ke kecamatan lain disekitar tempat tinggal.

Jarak tempuh penyediaan pakan untuk satu ekor sapi pada usaha pemeliharaan ternak sapi potong di Desa Sumber Sari berbeda-beda, peternak yang tidak menggunakan alat transportasi dan peternak yang menggunakan alat transportasi. Peternak menempuh jarak sejauh $113 \mathrm{~m}$ dalam penyediaan pakan ternak untuk memenuhi kebutuhan ternak yang dimiliki dengan berjalan kaki, sedangkan peternak yang menggunakan sepeda menempuh jarak sejauh 225 m. Peternak menggunakan sepeda motor menempuh jarak sejauh 211 dalam penyediaan pakan ternak untuk memenuhi kebutuhan ternak yang dimiliki sedangkan seorang peternak menggunakan mobil pick up menempuh jarak sejauh $1.000 \mathrm{~m}$.

\section{Lama Penyediaan Hijauan Pakan}

Lama penyediaan pakan untuk satu ekor ternak sapi pada usaha pemeliharaan ternak sapi potong dikelompokan berdasarkan alat transportasi yang digunakan oleh peternak dalam penyediaan pakan ternak. Lama penyedian pakan untuk satu ekor ternak sapi pada usaha pemeliharaan ternak sapi potong, disajikan pada Tabel 4.

Tabel 4. Lama penyedian pakan

\begin{tabular}{clc}
\hline No. & Alat Transportasi & $\begin{array}{c}\text { Lama waktu penyediaan pakan } \\
\text { (detik) }\end{array}$ \\
\hline 1. & Jalan kaki (a) & 1.167 \\
2. & Sepeda (b) & 2.270 \\
3. & Sepeda motor (c) & 1.584 \\
4. & Mobil Pick up (d) & 1.440 \\
\hline
\end{tabular}

Lama penyediaan pakan untuk satu ekor sapi pada usaha pemeliharaan ternak sapi potong di Desa Sumber Sari Kecamatan Loa Kulu Kabupaten Kutai Kartanegara, menunjukkan bahwa dalam penyediaan pakan seorang peternak tanpa menggunakan alat transportasi menghabiskan waktu selama 1.167 detik (19 menit 27 detik), seorang peternak dengan menggunakan sepeda menghabiskan waktu selama 2.270 detik (37 menit 50 detik), seorang peternak dengan menggunakan sepeda motor menghabiskan waktu selama 1.584 detik (26 menit 24 detik), sedangkan seorang peternak dengan menggunakan mobil pick up menghabiskan waktu selama 1.440 detik (24 menit).

Seorang peternak yang menggunakan sepeda dalam penyediaan pakan menghabiskan waktu paling lama dibandingkan dengan seorang peternak tanpa mengggunakan alat transportasi, hal tersebut dikarenakan sepeda yang digunakan oleh peternak dalam penyediaan pakan hanya sebagai alat bantu pembawa pakan sehingga dalam penyediaan pakan peternak tersebut sama seperti seorang peternak yang tidak menggunakan alat transportasi dalam penyediaan pakan akan tetapi jarak yang ditempuh lebih jauh dari seorang peternak tanpa alat transportasi. Seorang peternak yang menggunakan alat transportasi menghabiskan waktu yang lebih lama dibandingkan dengan 
seorang peternak yang tidak menggunakan alat transportasi, hal tersebut dikarenakan jarak yang ditempuh seorang peternak yang menggunakan alat transportasi lebih jauh dari pada jarak yang ditempuh oleh seorang peternak yang tidak menggunakan alat transportasi dalam penyediaan pakan.

\section{Lama Pemberian Hijauan Pakan}

Lama pemberian pakan pada usaha pemeliharaan ternak sapi potong dikelompokan berdasarkan cara peternak dalam memberikan pakan ternak di Desa Sumber Sari. Lama pemberian pakan untuk satu ekor ternak sapi pada usaha pemeliharaan ternak sapi potong, disajikan pada Tabel 5.

Tabel 5. Lama pemberian pakan

\begin{tabular}{ccccc}
\hline No. & Cara Pemberian Pakan & $\begin{array}{c}\text { Lama Waktu } \\
\text { Pemberian Pakan } \\
\text { (detik) }\end{array}$ & $\begin{array}{c}\text { Frekuensi } \\
\text { Pemberian Pakan } \\
\text { (Kali) }\end{array}$ & $\begin{array}{c}\text { Jumlah Pakan } \\
\text { yang diberikan } \\
(\mathrm{kg})\end{array}$ \\
\hline 1. & Secara langsung (a) & 28 & 1 & 6 \\
2. & Perlakuan Khusus (b) & 126 & 1 & 6 \\
\hline
\end{tabular}

Lama pemberian pakan disesuaikan oleh kebiasaan peternak dalam pemberian pakan ternak yaitu cara pemberian pakan. Cara pemberian hijauan pakan ternak di Desa Sumber Sari ada 2 yaitu diberikan secara langsung dan diberikan dengan perlakuan khusus. Cara pemberian pakan secara langsung adalah hijauan pakan ternak yang telah disediakan sebelumnya langsung diberikan pada ternak tanpa dipotong maupun dilakukan pemberian pakan tambahan sedangkan pakan yang diberikan dengan perlakuan khusus adalah hijauan pakan ternak yang telah disediakan sebelum dilakukan pemberian peternak akan memotong pakan terlebih dahulu atau peternak akan mencampur hijauan pakan dengan air, garam dan dedak sebelum dilakukan pemberian pakan kepada ternak.

Lama pemberian pakan secara langsung untuk satu ekor sapi pada usaha pemeliharaan ternak sapi potong di Desa Sumber Sari Kecamatan Loa Kulu Kabupaten Kutai Kartanegara adalah 28 detik sedangkan lama pemberian pakan dengan cara perlakuan khusus menghabiskan waktu lebih lama yaitu 126 detik (2 menit 6 detik) untuk 6 kg pakan per 1 kali pemberian pakan.

\section{Faktor-Faktor yang Mempengaruhi Lama Penyediaan Pakan}

Persamaan regresi linier berganda lama penyediaan pakan pada usaha pemeliharaan ternak sapi potong adalah sebagai berikut:

$$
Y=4,9892+0,3697 x_{1}+0,0683 x_{2}+0,0379 x_{3}
$$

Faktor-faktor yang mempengaruhi lama penyediaan pakan dalam usaha pemeliharaan sapi potong dari hasil analisis regresi linier berganda menunjukkan bahwa jarak tempuh $\left(X_{1}\right)$, jumlah pakan $\left(X_{2}\right)$ dan alat transportasi $\left(X_{3}\right)$ secara bersama-sama berpengaruh signifikan terhadap lama penyediaan pakan pada usaha pemeliharaan ternak sapi potong (Y). Hasil analisis regresi linier berganda menunjukkan bahwa jarak tempuh 
$\left(\mathrm{X}_{1}\right)$ mempengaruhi lama penyediaan pakan pada usaha pemeliharaan sapi potong $(\mathrm{Y})$ secara parsial atau masing-masing karena jarak tempuh $\left(X_{1}\right)$ berkolerasi positif dan berpengaruh signifikan terhadap variabel lama waktu penyediaan pakan (Y).

Jarak yang ditempuh oleh responden cukup jauh untuk penyediaan pakan ternak hal tersebut dikarenakan sebagian besar responden tidak memanfaatkan lahan budidaya hijauan pakan ternak dengan optimal, peternak beranggapan lahan budidaya hijauan pakan ternak merupakan sediaan pakan pada saat ketersediaan hijauan pakan ternak sudah terbatas dan saat peternak tidak memiliki waktu luang untuk menyediakan pakan dari tempat lain sedangkan sebagian responden lainnya tidak memiliki lahan bidudaya hijauan pakan ternak sehingga responden harus menempuh jarak yang cukup jauh dan tidak semua jalan yang ditempuh memiliki struktur yang baik untuk menyediakan hijauan pakan ternak.

Lahan budidaya hijauan pakan ternak mampu membantu dan memudahkan responden dalam penyediaan pakan apabila responden memiliki dan memanfaatkan dengan optimal. Musim hujan mengakibatkan beberapa lahan pengambilan hijauan pakan ternak tergenang air sehingga ketersediaan hijauan terbatas dan pada musin kemarau ketersediaan pakan terbatas. Muhakka et al., (2012) menyatakan ketersediaan hijauan yang semakin terbatas dapat diatasi dengan optimalisasi pemanfaatan hijauan seperti rumput budidaya yang mampu beradaptasi pada kondisi lahan. Kasus yang terjadi di sekitar gunung Salak, Jawa Barat, juga hampir sama, yaitu para peternak memanfaatkan rumput alam sebagai sumber bahan pakan ternaknya (Widarti \& Sukaesih, 2015).

Jumlah pakan $\left(\mathrm{X}_{2}\right)$ dan alat transportasi $\left(\mathrm{X}_{3}\right)$ berkolerasi positif akan tetapi berpengaruh tidak signifikan terhadap variabel lama waktu penyediaan pakan $(Y)$, hal tersebut dikarenakan jumlah pakan yang disediakan oleh peternak menyesuaikan dengan kemampuan peternak sehingga tidak menyesuaikan dengan jumlah ternak yang dimiliki dan bobot badan ternak yang dimiliki. Jumlah pakan yang disediakan menyesuaikan dengan kemampuan peternak baik kemampuan tenaga maupun waktu yang mayoritas peternak memiliki pekerjaan utama sebagai petani sehingga mengakibatkan pada penyediaan pakan peternak belum memperhatikan dan belum memperhitungkan kapasitas daya angkut yang efisien dari setiap unit alat transportasi yang digunakan untuk membawa hijauan pakan ternak. Kapasitas daya angkut untuk setiap kendaraan memiliki perbedaan pada spesifikasi kendaraan.

\section{Faktor-faktor yang Mempengaruhi Lama Pemberian Pakan}

Persamaan regresi linier berganda lama pemberian pakan pada usaha pemeliharaan ternak sapi potong adalah sebagai berikut:

$$
Y=-4,2469+1,9963 x_{1}+1,2771 x_{2}-0,0073 x_{3}
$$


Faktor-faktor yang mempengaruhi lama pemberian pakan pada usaha pemeliharaan sapi potong dari hasil analisis regresi linier berganda menunjukkan cara pemberian pakan $\left(X_{1}\right)$, frekuensi pemberian $\left(X_{2}\right)$ dan jumlah pakan $\left(X_{3}\right)$ secara bersama-sama berpengaruh terhadap lama penyediaan pakan pada usaha pemeliharaan ternak sapi potong $(\mathrm{Y})$. Hasil analisis regresi linier berganda menunjukkan bahwa cara pemberian pakan $\left(X_{1}\right)$ dan frekuensi pemberian $\left(X_{2}\right)$ mempengaruhi lama pemberian pakan pada usaha pemeliharaan sapi potong $(Y)$.

Cara pemberian pakan $\left(\mathrm{X}_{1}\right)$ berkolerasi positif dan berpengaruh signifikan terhadap variabel lama pemberian pakan $(\mathrm{Y})$. Cara pemberian pakan berpengaruh signifikan terhadap lama waktu pemberian pakan hal tersebut dikarenakan peternak memiliki kebiasaan yang berbeda-beda dalam pemberian hijauan pakan ternak yaitu diberikan secara langsung dan diberikan dengan perlakuan khusus.

Frekuensi pemberian pakan $\left(\mathrm{X}_{2}\right)$ berkolerasi positif dan berpengaruh signifikan terhadap variabel lama waktu pemberian pakan (Y). Frekuensi pemberian pakan berpengaruh signifikan, hal ini dikarenakan responden memiliki kebiasaan yang berbedabeda dalam pemberian pakan untuk satu hari. Suresti dan Wati (2012) menyatakan ternak yang dipelihara dengan sistem intensif, hijauan yang diberikan berupa rumput gajah, benggala, raja dan rumput lapang. Pemberian pakan rata-rata $40 \mathrm{~kg} \mathrm{ekor}^{-1}$ hari $^{-1}$ dengan frekuensi pemberian pakan 2 kali sehari yakni pagi dan sore.

Jumlah pakan $\left(\mathrm{X}_{3}\right)$ berkolerasi positif, akan tetapi berpengaruh tidak signifikan terhadap variabel lama waktu pemberian pakan (Y), hal tersebut dikarenakan jumlah pakan yang diberikan berdasarkan dugaan peternak akan kebutuhan pakan ternak sehingga waktu yang diperlukan tidak terlalu lama.

\section{Kesimpulan}

1. Lama penyediaan pakan oleh seorang peternak dalam menyediakan hijauan pakan untuk 1 ekor sapi potong di Desa Sumbersari, Kecamatan Loa Kulu adalah 19 menit 27 detik hingga 37 menit 50 detik.

2. Lama pemberian pakan oleh seorang peternak terhadap 1 ekor sapi berkisar antara 28 detik hingga 2 menit 6 detik, tergantung dari cara dam frekeunsi pemberian pakan.

3. Jarak yang ditempuh oleh seorang peternak dalam memperoleh hijauan pakan berkisar antara $113 \mathrm{~m}$ hingga $1.000 \mathrm{~m}$.

\section{Daftar Pustaka}

Badan Pusat Statistik Kabupaten Kutai Kartanegara. (2016a). Kutai Kartanegara Dalam Angka. Badan Pusat Statistik Kabupaten Kutai Kartanegara: Tenggarong.

Badan Pusat Statistik Kabupaten Kutai Kartanegara. (2016b). Statistik Daerah Kecamatan Loa Kulu Tahun 2016. Badan Pusat Statistik Kabupaten Kutai Kartanegara: Tenggarong. 
Darmawan, D. (2013). Metode Penelitian Kuantitatif. PT Remaja Rosdakarya: Bandung.

Hasan, I. (2005). Pokok-pokok Materi Statistik 2 (Statistik Inferensif). PT Bumi Aksara: Jakarta.

Muhakka, Napoleon, A., dan Rosa, P. (2012). Pengaruh pemberian pupuk cair terhadap produksi rumput gajah Taiwan (Pennisetum purpureum Schumach). Jurnal Peternakan Sriwijaya vol. 1 (1): 48-54.

Siregar, S. (2014). Statistik parametrik untuk penelitian kuantitatif. Bumi Aksara: Jakarta.

Suresti, A. dan Wati, R. (2012). Strategi Pengembangan Usaha Peternakan Sapi Potong di Kabupaten Pesisir Selatan. Jurnal Peternakan Indonesia, vol. 14(1): 249-262.

Widarti, A., Sukaesih. (2015). Keragaman jenis pakan ternak dan ketersediaannya di wilayah sekitar Taman Nasional Gunung Halimun Salak. Prosiding Seminar Nasional Masyarakat Biodiversitas Indonesia Vol. 1 (7): 1565-1569. 